\title{
Pengaruh Latihan Squat Jump Terhadap Kemampuan Jump Service dalam Permainan Bola Voli di SMAN 2 Labuapi
}

\author{
Moh. Ihsan \\ SMA Negeri 2 Labuapi, Kabupaten Lombok Barat \\ Corresponding Author. Email: moh.ihsan488@gmail.com
}

\begin{abstract}
This study aims to determine the effect of squat jump training on jump service in volleyball games for students of SMAN 2 Labuapi. The approach used in this research is the quantitative approach, using the experimental method. The population used in this study was 10 athletes at SMAN 2 Labuapi, and the samples were 10 athletes. The instrument used is the squat jump test. The data is processed using statistical formulas in the form of calculating the average value, standard deviation, and the two-mean test. The data analysis in this study used the t-test at a significant level of 0.05 . The results obtained are that there is an effect of Squat Jump training on Jump Service in volleyball games at the SMAN 2 Labuapi club. By testing the t count of 2.92 and $t$ table of 1.86 , so there is a significant difference between the data before and after being given treatment.
\end{abstract}

\begin{abstract}
Abstrak: Penelitian ini bertujuan untuk mengetahui Pengaruh Latihan Squat Jump Terhadap Jump Service Dalam Permainan Bola Voli pada siswa SMAN 2 Labuapi. Pendekatan yang digunankan dalam penelitian ini yaitu pendekatan Kuantitatif, dengan menggunakan metode Eksperimen. Populasi yang digunakan dalam penelitian ini atlet SMAN 2 Labuapi yang berjumlah 10 atlet, sampel yang diambil sebanyak 10 atlet. Instrument yang digunakan adalah tes squat jump. Data diolah dengan menggunakan rumus statistik dalam bentuk perhitungan nilai rata-rata, standar deviasi, dan uji dua rata-rata. Analisis data dalam penelitian ini menggunakan uji-t pada taraf signifikan 0,05. Hasil penelitian yang diperoleh adalah terdapat pengaruh latihan Squat Jump terhadap Jump Service dalam permainan bola voli pada klub SMAN 2 Labuapi. Dengan pengujian thitung sebesar 2,92 dan tabel sebesar 1,86, sehingga terdapat perbedaan yang signifikan antara data sebelum dan sesudah diberikan perlakuan.
\end{abstract}

How to Cite: Ihsan, M. (2020). Pengaruh Latihan Squat Jump Terhadap Kemampuan Jump Service dalam Permainan Bola Voli di SMAN 2 Labuapi. Jurnal Teknologi Pendidikan, 5(2), 181-185. Retrieved from http://ojs.ikipmataram.ac.id/index.php/jtp/article/view/3062

\section{Pendahuluan}

Permainan bola voli service merupakan suatu tindakan yang di lakukan untuk memulai atau mengawali dalam permainan bola voli. Dalam permainan bola voli service merupakan serangan awal yang harus dilakukan dengan hati- hati.Oleh karena setiap orang yag melakukan service pasti akan membuat bola service yang mematikan lawan,atau mengarahkan bola kepada lawan yang passingnya tidak terlalu bagus. Service yang di lakukan dengan baik bisa mematikan lawan atau paling tidak lawan akan kesulitan menyusun serangan bahkan mampu mendapatkan point.

Pada mulanya service hanya merupakan pukulan pembuka untuk memulai suatu permainan sesuai dengan kemajuan permainan, tetapi jika ditinjau dari sudut taktik sudah merupakan suatu serangan awal untuk mendapatkan nilai agar suatu regu berhasil meraih kemenangan. Jump service adalah cara melakukan pukulan permulaan di daerah service dengan melompat setelah bola dilambungkan dengan satu tangan atau dua tangan 
(Syarifuddin, 2007). Service lompat dilakukan dengan bola dilambungkan dengan satu atau dua tangan. Begitu bola dilambungkan diikuti dengan melompat dan diusahakan bola berada di atas depan kepala. Bila bola telah berada di atas depan kepala maka segeralah tangan kanan dipukulkan pada bola secepatnya.

Jika belum bisa melakukan service yang mematikan, paling tidak bola service melewati net dan jatuh di area lawan sehingga permainan bisa berjalan. Namun sebaliknya jika service Anda tidak melewati net maka pihak lawan akan mendapatkan point dan tim kalian merugikan tim Anda. Oleh karena itu, kegagalan dalam melakukan service, sering di anggap memberikan point kepada lawan secara cuma-cuma pada tim lawan. Service merupakan salah satu senjata ampuh untuk mengacaukan serangan kombinasi lawan, sebuah team memerlukan minimal $2 \mathrm{~s} / \mathrm{d} 3$ orang jump service yang dapat mengacaukan irama permainan lawan.Untuk dapat melakukan jump servicedapat dilatih dengan menggunakan latihan squat jump. Squat Jump adalah sikap jongkok sebelah kaki didepan, melompat keatas sampai kaki lurus dan kembali bersikap semula dengan menukar kaki di depan ganti kebelakang. Squat jump ialah semacam bentuk olahraga dengan cara dua tangan dikaitkan di belakang kepala, kemudianberjongkok hingga posisi squat, tekan ujung kaki dan dorong tubuh ke udara setinggi mungkin, dan Saat turun, segera tekuk lutut, turun kembali ke posisi squat dan melompat lagi (Ansori, 2011). Squat jump merupakan bentuk latihan dengan merendahkan posisi tubuh sampai setengah jongkok, kedua tangan saling berkait dibelakang kepala, bergerak keatas dengan kuat, dan menjaga kepala tetap tegak, menurut Sajoto dalam Rokhman (2011). Latihan ini bermula dari posisi tubuh yang sedikit jongkok dengan posisi kaki dibuka selebar bahu, kemudian kedua tangan saling berkait dibelakang kepala. Gerakan dari latihan squat jump ini dengan meloncat vertikal sekuat mungkin, usahakan posisi kaki lurus ketika melayang di udara, pendaratan kembali ke posisi awal dan lakukan secara berulang- ulang tergantung set dan repetisi.

Penelitian ini dilaksanakan pada klub voli SMAN 2 Labuapi. Alasan dilakukannya penelitian ditempat tersebut dikarenakan berdasarkan hasil obsevasi atau pengamatan penulis ketika menyaksikan pertandingan yang diadakan SMAN 2 Labuapi pada tahun 2018, Dimana beberapa pertandingan yang dilakukan SMAN 2 Labuapi. penulis menyaksikan secara langsung, dari beberapa pertandingan yang diikuti voli Klub SMAN 2 Labuapi, pada saat melakukan jumpservice masih belum sempurna, dimana kebanyakan atlet yang bermain volimasih kesulitan dalam melakukan jump service, dikarenakan untuk melakukan jump service harus melompat, akan tetapi atlet voliKlub SMAN 2 Labuapi. kurang dalam melakukan latihan squat jump, mereka hanya melakukan latihan dasar penguatan otot dan fisik seperti push up dan lari 15 menit. Sehingga untuk meningkatkan kemampuan jump service bagi atlet voli Club SMAN 2 Labuapi haruslah diberikan latihan yang berfungsi untuk meningkatkan lompatan, salah satunya yaitu dengan latihan squat jump. Adapun tujuan penelitian ini adalah untuk menganalisis pengaruh latihan squat jump terhadap kemampuan jump servive dalam permainan bola voli di SMAN 2 Labuapi.

\section{Metode Penelitian}

Pendekatan yang digunakan dalam penelitian ini yaitu pendekatan kuantitatif dimana pengolahan data yang digunakan menggunakan rumus. Dalam suatu penelitian perlu menerapkan metode yang sesuai dan dapat mengungkapkan suatu permasalahan. Keberhasilan suatu penelitian ilmiah tidak akan terlepas dari suatu metode yang digunakan. Dalam penelitian ini peneliti menggunakan metode penelitian eksperimen dengan teknik tes yang dianggap mampu memberikan gambaran tentang pembuktian hasil penelitian. Di dalam 
penelitian eksperimen ada perlakuan (treatment) yang diberikan kepada kelompok-kelompok tertentu, menurut Sugiyono metode penelitian eksperimen adalah sebuah metode yang digunakan untuk mencari pengaruh sebuah perlakuan tertentu terhadap objek- objek yang ingin diteliti dalam kondisi yang terkendalikan (Sugiyono, 2012).

Populasi penelitian adalah keseluruhan sampel penelitian atau objek yang akan diteliti (Notoadmojo, 2005). Populasi dalam penelitian ini adalah seluru atlet futsal SMAN 2 Labuapi yang berjumlah 10 atlet. Sampel adalah sebagian yang diambil dari keseluruhan objek yang diteliti dan dianggap mewakili seluru populasi. Teknik pengambilan sampel dalam penelitian ini adalah total sampling yakni teknik pengambilan sampel dimana jumlah sampel sama dengan populasi (Sugiyono 2007). Alasan mengambil total sampling karena menurut jumlah populasi yang kurang dari 100 seluru polasi dijadikan sampel penelitian semuanya. Sampel yang diambil dari penelitian ini adalah 10 atlet.

Menurut Sugiyono (2009), menyatakan bahwa instrumen penelitian adalah suatu alat yang digunakan mengukur fenomena alam maupun sosialyang diamati. Keberhasilan suatu penelitian banyak ditentukan oleh instrumen yang digunakan, sebab data yang diperoleh untuk menjawab pertanyaan penelitian dan menguji melalui instrumen tersebut.

Tabel 1. Norma Tes Kemampuan Jump Service

\begin{tabular}{|c|c|c|}
\hline \multirow{2}{*}{ Kriteria } & \multicolumn{2}{|c|}{ Nilai } \\
\cline { 2 - 3 } & Laki-Laki & Perempuan \\
\hline Baik Sekali & $22-25$ & $22-25$ \\
\hline Baik & $19-21$ & $19-21$ \\
\hline Sedang & $14-28$ & $14-28$ \\
\hline Kurang & $9-13$ & $9-13$ \\
\hline Kurang Sekali & $5-8$ & $5-8$ \\
\hline
\end{tabular}

Teknik analisis data merupakan suatu langkah penting yang dilakukan oleh peneliti untuk menjabarkan atau menganlisa data yang diperoleh sehingga didapatkan hasil dalam penelitian yang telah dilakukan.Dalam penelitian ini peneliti menggunakan rumus-rumus statistik yaitu dengan t-hitung.

\section{Hasil Penelitian dan Pembahasan}

Berdasarkan hasil pengolahan data kemampuan jump service diperoleh nilai rata-rata, standar deviasi dan uji t seperti terlihat pada tabel berikut ini :

Tabel 2. Rekapitulasi Nilai Rata-Rata, Standar Deviasi dan Nilai Uji Beda Dua RataRata Kemampuan Jump Service Pada Atlet Voli SMAN 2 Labuapi.

\begin{tabular}{|c|l|c|c|c|c|c|c|}
\hline \multirow{2}{*}{ No } & \multirow{2}{*}{ Variable Pengukuran } & \multicolumn{2}{|c|}{ Nilai Rata-Rata } & \multicolumn{2}{|c|}{ Nilai Standar Deviasi } & \multicolumn{2}{|c|}{$\begin{array}{c}\text { Uji “'t' } \\
(\boldsymbol{\alpha}=\mathbf{1 0 \%})\end{array}$} \\
\cline { 3 - 8 } & & $\begin{array}{c}\text { Tes } \\
\text { awal }\end{array}$ & $\begin{array}{c}\text { Tes } \\
\text { Akhir }\end{array}$ & Tes awal & Tes Akhir & $\begin{array}{c}\text { Thit } \\
\text { Tta } \\
\text { b }\end{array}$ \\
\hline 1 & Jump Service & 15 & 21 & 2,30 & 2,40 & 2,92 & 1,86 \\
\hline
\end{tabular}

Sumber: SMAN 2 Labuapi 2019 
Derajat peningkatan latihan squat jump terhadap kemampuan jump service dalam permainan bola voli pada klub SMAN 2 Labuapi dapat dilihat dari besarnya uji beda ratarata yang diperoleh yaitu thitung sebesar 2,92 sedangkan untuk t-tabel sebesar 1,86. Berdasarkan analisa yang telah dilakukan oleh peneliti diatas, maka terlihat terdapat pengaruh yang signifikan antara latihan squat jump terhadap jumpservice pada Atlet SMAN 2 Labuapi. Peningkatan kemampuan jump service dikarenakan adanya latihan squat jump. Latihan squat jump merupakan suatu latihan yang dapat dilakukan untuk mendukung kemampuan jump service. Dalam jump service dibutuhkan lompatan yang maksimal yang berguna untuk memberikan tembakan bola ke arah lawan dengan kecepatan dan kekuatan yang kuat, sehingga bola yang di service dapat melesat dengan tajam dan menghasilkan poin (angka).

Jump Service adalah salah satu istilah tehnik memulai permainan bola voli dengan melakukan lompatan. Ada bermacam-macam gaya atau cara yang bisa digunakan untuk melakukan jenis serviceyang satu ini. Nilai seni dari tehnik seperti ini adalah bagaimana menggabungkan tekanan, kekuatan dan feeling pemain terhadap bola yang digunakan dalam permainan. Latihan squat jump adalah lompat- lompat di tempat yang diawali dengan jongkok (squat). Bentuk latihan otot kaki yaitu latihan squat jump yaitu gerakan melompat keatas sehingga kedua kaki lurus dan saat turun kedua lutut agak ditekuk dengan posisi pinggul hanya sedidit diturunkan. Squat jump merupakan bentuk latihan untuk melatih dan meningkatkan daya tahan, power otot tungkai. Latihan squat jump dimulai dengan posisi tegak lurus dengan kaki ditempatkan selebar bahu, sambungkan jari-jari tangan dan tempatkan telapak tangan ke belakang kepala, gerakan ini menekan lutut dan pangkal paha. Adapun rangkaian gerakan dimulai dengan tekanan kebawah dan dengan cepat melompat ke atas sama tingginya kemungkinan dengan pendaratan posisi setengah jongkok. Pada latihan squat jump atlet melompat keatas secara berulang-ulang tanpa menggunakan media, sehingga kadang kala yang nampak adalah variasi ketinggian lompatan yang berbeda- beda.Diawalawal latihan lompatan atlet bisa maksimal tapi setelah beberapa menit selanjutnya menjadi terbatas. Begitu juga dengan irama gerakan pada saat melompat juga mempengaruhi, karena atlet hanya fokus pada waktu yang tersedia dan melupakan irama gerakan pada saat melompat (tidak terkontrol).

\section{Kesimpulan}

Berdasarkan hasil penelitian yang diperoleh adalah terdapat pengaruh latihan Squat Jump terhadap Jump Service dalam permainan bola voli pada klub SMAN 2 Labuapi. Dengan pengujian thitung sebesar 2,92 dan ttabel sebesar 1,86, sehingga terdapat perbedaan yang signifikan antara data sebelum dan sesudah diberikan perlakuan. Dengan demikian metode latihan squat jump ini dapat digunakan sebagai salah satu bentuk latihan untuk meningkatkan daya ledak otot tungkai. Latihan squat jump bila diterapkan secara teratur dan terprogram, serta disiplin yang tinggi sangat mempengaruhi hasil kemampuan lompatannya pada saat melakukan jump service. Sehingga latihan squat jump ini dapat diterapkan oleh para pelatih untuk meningkatkan daya ledak otot tungkai. Sehingga dalam melakukan latihan selama selama 16 kali pertemuan, sangat berpengaruh terhadap peningkatan kemampuan jump service pada atlet SMAN 2 Labuapi 


\section{Daftar Pustaka}

Ahmadi, Nuril. (2007). Panduan Olahraga Bola Voli. Era Pustaka Utama.

Aip Syarifuddin dan Muhadi. (2007). Pendidikan Jasmani dan Kesehatan. Jakarta. : Depdikbud.

Arikunto, S. (2010). Prosedur Penelitian Suatu Pendekatan Praktik. Jakarta: Rineka Cipta.

Arikunto, Suharsimi., dkk. (2008). Penelitian Tindakan Kelas. Jakarta: Bumi. Aksara.

Arikunto, S. (2006). Metode Penelitian Kualitatif. Jakarta: Bumi Aksara.

Ashari, L., \& Djuniadi, D. (2015). Pengembangan Instrumen Penilaian unjuk Kerja dengan Model Peer Asssessment System untuk Mata Pelajaran Penjasorkes pada Pokok Bahasan Permainan Bola Voli. Jurnal Kependidikan: Jurnal Hasil Penelitian dan Kajian Kepustakaan di Bidang Pendidikan, Pengajaran dan Pembelajaran, 1(1). doi:https://doi.org/10.33394/jk.v1i1.399

Bachtiar. (2007). Materi Pokok Permainan Besar II Bola Voli.Jakarta : Universitas

Beutelstahl, Dieter. (2007). Belajar Bermain Bola Voli.Bandung:CV Pioner Jaya.

Bompa. (2004). Klasifikasi Latihan. Pustaka Indonesia.

Chandra, Sodikin dan Achmad, Esnoe Sanoesi. (2010). Pendidikan Jasmani Olahraga dan Kesehatan. Jakarta: Pusat Perbukuan Kementrian Pendidikan Nasional.

Dikdik. (2007). Latihan Kondisi Fisik, Klinik Kepelatihan Pelatih. Gramedia. Jakarta

Haryoko, Sapto. (1999). Efektifitas Pemanfaatan Media.Teknolagi Informasi Sebagai Optimalisasi Model Pembelajaran.

Ismayanti. (2006). Tes dan Pengukuran Olahraga.University Press.

M. Yunus. (2012). Olah Raga Pilihan Bola Voli. Jakarta : Departemen pendidikan dan kebudayaan.

Muhasyim, M. (2016). MENINGKATKAN HASIL BELAJAR PENJASKES TENTANG SERVIS PERMAINAN BOLA VOLLY DENGAN PENDEKATAN PEMBELAJARAN DRIIL DAN BERMAIN PADA SISWA KELAS IV SD NEGERI JEKANI 3. Jurnal Teknologi Pendidikan, 1(2), 10-24. Retrieved from http://ojs.ikipmataram.ac.id/index.php/jtp/article/view/608

Notoadmojo. (2005). Metodelogi Penelitian Kesehatan.Jakarta : Rineka Cipta.

Susilawati, I., \& Primayanti, I. (2018). Meningkatkan Kekuatan Otot Quadriceps pada Pemain Sepak Bola Melalui Latihan Delorme. Jurnal Kependidikan: Jurnal Hasil Penelitian dan Kajian Kepustakaan di Bidang Pendidikan, Pengajaran dan Pembelajaran, 4(2), 158-162. doi:https://doi.org/10.33394/jk.v4i2.1124

Zainuri, K. (2020). Peningkatan Hasil Pembelajaran Lompat Jauh Melalui Pendekatan Bermain Longu pada Siswa Kelas IV SDN 37 Ampenan. Jurnal Paedagogy, 7(1), 3542. doi:https://doi.org/10.33394/jp.v7i1.2513 